\title{
Handling Policy on Corruption Crime in Polres Tasikmalaya
}

\author{
Imanudin $^{1}$
}

Abstract. In this study, will be discussed are: the handling of corruption in Polres Tasikmalaya, there are obstacles in the Handling of Corruption in the Polres Tasikmalaya and solutions in dealing with the constraints in the handling of Corruption in Polres Tasikmalay. The method used in this research is normative juridical approach used to determine the extent to which the principles of the law, the synchronization vertical / horizontal, and systemic law is applied, which is based on secondary data. Based on the results of this study are very large role of Police in law enforcement to eradicate corruption. But the weakness of the laws that regulate the authority of the Police in the investigation of corruption resulted in the ineffectiveness of the investigation of cases of corruption by the police. Police Investigator action in the process of investigation of corruption practiced by the investigator in Polres Tasikmalaya, there were always obstacles that result in delays / delays in the investigation of corruption. Propose the addition of Human Resources Police as one of the measures to meet the needs of a shortage of human resources, and / or exploit the existing potential according to ability and knowledge possessed, where one of her given training and education for the field duties and functions authority relating to the handling of Corruption. Provide guidance / courses / training related to IT (Information Technology), especially in connection with the handling of Corruption;

Keywords: Policy; Crime; Corruption.

\section{Introduction}

Corruption is an act that not only can harm the state finances but also can cause loss on people's economy. Barda Nawawi Arief found, corruption is a reprehensible act, cursed and hated by most people; not only by the people and the nation of Indonesia but also by the community of nations of the world. ${ }^{2}$

Regarding other forms of corruption itself, Syed Hussein Alatas, as cited by the Nyoman Serikat Putra Jaya have divided into 7 typology of corruption, namely ${ }^{3}$ :

- Transactive Corrution, here demonstrate to their mutual agreement between the donor and the recipient for the benefit of both parties and actively sought to achieve gains by both;

- Extortive Corruption is a kind of corruption in which the provider is forced to bribe in order to prevent losses being threatened themselves, their interests, or people and things he cherishes;

- Investive Corruption is the victim of corrupt behavior with extortion. Corruption is in order to defend themselves, such as the provision of goods or services without

\footnotetext{
${ }^{1}$ Student of Masters (S2) of Law Faculty of Law Unissula and Police email imanudin653@gmail.com

${ }^{2}$ Muladi dan Barda Nawawi Arief Bunga Rampai Hukum Pidana Bandung Alumni p. 133

3 Jaya Nyoman Serikat Putra 2005 Tindak Pidana Korupsi Kolusi dan Nepotisme di Indonesia Semarang Badan Penerbit UNDIP p.14-15
} 
any direct linkage with certain advantages, in addition to the advantages envisaged to be acquired in the future;

- Nepotistic Corruption is a designation that is not valid against a friend or relative to hold public office, or actions that provide treatment that promotes in the form of money or other forms, to them, is contrary to the norms and regulations;

- Defensive Corruption, here giver innocent but guilty of the recipient. For example: a ruthless businessman who wanted the right to belong to someone, not the sinner give to the authorities as part of the treasure to save the rest of the property;

- Autogenic Corruption is a form of corruption that does not involve other people and the culprit was alone;

- Supportive Corruption, here does not directly involve money or other forms of remuneration. Measures are actions taken to protect and strengthen the existing corruption.

The development of corruption in Indonesia is still relatively high, while its eradication is still very slow, Romli Atmasasmita, stated that, Corruption in Indonesia is already a flu virus that spreads to the entire body of government since the 1960s steps eradication was still halting until now. ${ }^{4}$ Further, he said that corruption also related to power due to the power authorities could abuse their power for personal interests, family and cronies. ${ }^{5}$

Policies issued by the President of the Republic of Indonesia on things that are policies that can not be criminalized and administrative matters resolved administratively at least influence the handling problems of corruption now, with the president's policies are then addressed the law enforcement agencies including the Indonesian National Police and the General Attorney of the Republic of Indonesia, one of the things that are important from both institutions on the handling of corruption cases is to make the village fund Cooperation Agreement between the Ministry of the interior, Attorney of the Republic of Indonesia and the Indonesian National Police on Coordination Officers Internal Control Government (APIP) with law enforcement authorities (APH) in the handling of reports on complaints that potential corruption in organizing local government, the agreement created new problems especially in Article 6 of subjects who reported or brought, why here a new problem arises because the legal subjects reported / complained by the people must be active,means indirectly when the acts allegedly committed by the head of the village when they served yet reported or brought when the question already out of office then automatically parties are given the authority to supervise and conduct an investigative audit (APIP) at the District could not process anymore, while qualified to perform the process of investigation of corruption is the result of the audit that will or may detect losses to the state or not, it was one of the obstacles faced by investigators of corruption in Polres Tasikmalaya station, because when investigating corruption, Police at Polres Tasikmalaya asking to do an investigative audit cases alleged corruption committed by former village chief Indra Jaya sub-district Sukaratu Tasikmalaya regency be a problem since the beginning

\footnotetext{
${ }^{4}$ Romli Atmasasmita 2004 Sekitar Masalah Korupsi Aspek Nasional da Aspek Internasional Bandung Mandar Maju p. 1.

${ }^{5}$ Ibid.
} 
of the APIPs / Inspectorate Tasikmalaya district rejected the request of the investigating authorities for the village chief Indrajaya already longer served.

The formulation of the problem is as follows: How policy on Corruption Crime in Polres Tasikmalaya? Are there obstacles in Handling of Corruption in Polres Tasikmalaya? How does the solution in addressing the constraints in the handling of Corruption in Polres Tasikmalay?

\section{Research Methods}

The method used this research is normative juridical approach method is used to determine the extent to which the principles of the law, the synchronization vertical / horizontal, and systemic law is applied, which is based on secondary data. Specifications of this research is descriptive.

\section{Results and Discussion}

\subsection{Handling Policy Corruption in Polres Tasikmalaya}

Implementation of criminal investigations of corruption committed in the city of Tasikmalaya Police Jurisdiction and his staff are in accordance with the principles of the importance of an investigator who apply, namely:

- Legallitas principle In interviews with investigators who were respondents in this study, namely the City of Tasikmalaya Police investigators agree that the process of investigation by the City of Tasikmalaya Police in accordance with the law applicable to the institution in carrying out investigations.

Police investigations conducted as a cornerstone of departure Tasikmalaya City Police in carrying out its duties and authorities conduct an investigation and prosecution of corruption refers to Act No. 31 of 1999 jo. Act No. 20 of 2001 on Amendments to the Act No. 31 of 1999 on Corruption Eradication as material law and Act No. 8 of 1981 on Criminal Proceedings as a formal criminal law.

- Principle of Presumption of Innocence The presumption of innocence is one proof of the Criminal Procedure Code tribute to human rights. This is in line with the opinion of the City of Tasikmalaya Police investigators. In terms of implementation of the investigations always respect the rights of suspects itself, as is currently the rule of law in Indonesia has adhered to the principle of aqusatoir so investigators carry out investigations using methods of investigation by using violence and not appropriate at the present time due to the recognition of the defendant no longer be evidence.

- Principle Fast, Simple and Cost Lightweight

Based on interviews with informants in this study, the implementation of this principle has been cultivated as much as possible to be implemented in the investigation process, but sometimes constrained by suspects and witnesses are uncooperative in providing information so that the investigation process is not quickly resolved.

- Functional differentiation principle 
If the investigations conducted by police, the police only have the task to a corruption investigation and after completion of the investigation the prosecutor assigned to carry out the prosecution.

- The principle of Mutual Coordination

In the case where the precedence investigator, is investigator has sufficient evidence in terms of knowing an act of corruption. So there is always coordination between police and prosecutors when conducting an investigation in order to avoid the cone overlap between the two agencies.

Besides the police in Polres Tasikmalaya started an investigation against corruption, Tasikmalaya Police investigator will always coordinate with the Public Prosecutor and reported to the Police of West Java and West Java High Court on cases handled. But on the contrary the Commission itself does not knick supervision and oversight to the Prosecutor in Tasikmalaya area. Thus we can conclude that the law enforcement agencies in the region of Polres Tasikmalaya has been carrying out an investigation in accordance with the principle of mutual coordination between law enforcement agencies.

- The principle of Equality Before the Law

Barriers to corruption is also implicit in the one principle that applies in criminal law which reads "legi derogate lex specialist generalist". When the daily practice in handling corruption cases to form an image as if the cone overlap of authority between sub-systems within the criminal justice system. Image or views formed about who is authorized to conduct investigations on corruption cases. Cone overlap of authority was not expected to affect the process penagakan corruption law, which if it happened would surely can worsen the image of law enforcement corruption cases in which the world. ${ }^{6}$

- Principle Akusator and Inqusitoir

In the implementation of an investigation of course use the approach of the criminal justice system in force, it is in accordance with the opinion of Atmasasmita Romli, namely ${ }^{7}$, "The approach of the criminal justice system focuses on the coordination and synchronization with penngguna accompanies supervision and control of power by the components of the criminal justice (police, prosecutors, Courts and Prisons) and using the law as an instrument to establish the administration of jaustice".

\subsection{Factors of Affecting Investigation of Corruption in Polres Tasikmalaya}

Of the factors that led to evidence of corruption cases investigated by the Police described, of researchers explained that as an assignment as investigator corruption hampered because:

- Not easy agencies or private investigators provided the documents requested on the grounds should be as license management (bureaucracy).

\footnotetext{
${ }^{6}$ Sahuri Lasmadi "Tumpang tindih kewenangan penyidikan pada tindak pidana korupsi dalam perspektif system peradilan pidana" Makalah Fakultas Hukum Jambi. p. 4

${ }^{7}$ Romli Atmasasmita Prospek Penanggulangan Korupsi di Indonesia Memasuki Abad XXI : Suatu Reorientasi atas Kebijakan Hukum Pidana di Indonesia 1999 Bandung p. 34
} 
- The requested document was not given in full for reasons other documents are already lost.

- Terms of audit by BPK audit results must be complete to obtain legal legitimacy.

- Particulars of the testimony or statements of experts and documents must be provided by the authority which has competence consistently, so the investigation disrupted.

- Sometimes there are differences of perception between law enforcement (investigator with the prosecutor) which resulted in the investigation stalled.

- Intrinsically more choked up when the cases investigated by the police with the understanding that the trial of cases investigated by the prosecutor to be carried on its own, clearly different from the continuing work of others. Examples presented witnesses at the hearing and a personal understanding of these witnesses will be easier for the prosecutor because the investigation has been known since the further and deeper, different from the file of the Police for the new prosecutor familiar with personal address or witnesses before the trial.

- Even if there is, would seem to be proof against the perpetrators and witnesses of corruption cases to protect each other.

- The documents were removed or hidden.

- The process of calculating the amount of loss the country needs a relatively long time.

So that attempts by investigators to remove the obstacles to judicial and non-judicial in the investigation of corruption cases in the Polres Tasikmalaya. For barriers juridical because it is already in the scope of national legislation, the Polres Tasikmalaya could not have access to it can only be input to the management of a higher, while for blocking non-juridical Polres Tasikmalaya of coordination to all the agencies in addition to reporting to the Chairman as tiered.

\subsection{The solution in addressing the constraints in the handling of Corruption in Polres Tasikmalaya}

The measures undertaken by the Polres Tasikmalaya in developing criminal investigations of corruption are:

- Scheduled Investigation of Corruption Cases In Priority Scale.

Police paradigm emphasizes appropriate services, protection and protection while the law enforcement community as a means to realize Kamtimbas, then the policy direction the Police in combating corruption in the area, are:

- Law enforcement activities by the police, intended to give effect detern for perpetrators and potential perpetrators;

- Investigation of corruption cases, in addition to proving the act the perpetrator, as well as maximum as possible to restore the country's financial losses;

- To take into account the level of investigation of corruption, such as cases involving Regent / Mayor is handled by the Regional Police (Polda);

- To avoid alternating docket of cases of corruption, the investigation has been carried out since the beginning of coordination and communication with the Attorney; 
- Intensify coordination and communication with relevant agencies to optimize corruption investigations;

- Increase the credibility of member / Investigator.

- Improving human resources

West Java Police to take steps responsive by taking measures such as:

1) Proposed the addition of personnel investigator assigned exclusively to handle cases of corruption on top unity.

2) Sending personnel to be educated and trained investigators kasu handling of corruption, in order to enhance the ability profesonalisme and investigators in handling and eradication of corruption.

3) Reward and Punishment provide the personnel who work or excel in handling corruption cases. Instead it will impose penalties on personnel considered negligent or unable to carry out the duties and obligations ndalam combating corruption.

4) Providing technical guidance and direction in the form Handbook, letters, telegrams from the highest unit of the Mabes Polri to units of territorial underneath.

\section{Closing}

\subsection{Conclusion}

Based on the description that has been the author convey in writing the study, the authors conclude in the description can be shorter in this chapter as follows:

- Policy on Corruption Crime in Polres Tasikmalaya

The criminal justice system is said to be effective if the proportion of the settlement (cleareance rate), the proportion of prosecutions (Prosecution rate), the proportion of criminal (conviction rate), the speed warning case (speedy trail), is quite high, while recidivists (recall to prison) is low. The role of the police in tackling corruption was organized through the investigation, the police has acted effectively tackling corruption, where the rate of settlement by the investigator is generally reached $70 \%$, while the speed of handling cases quite well within the limits of the time period of detention by the investigator.

- Factors hindering the effectiveness of the Police Investigator Role in Corruption Investigation

Police investigators that measures in the process of investigation of corruption practiced by the investigator in Polres Tasikmalaya, there were always obstacles that result in delays / delays in the investigation of corruption.

- Solutions constraints in Handling of Corruption in Polres Tasikmalaya

- Propose the addition of Human Resources Police as one of the measures to meet the needs of a shortage of human resources, and / or exploit the existing potential according to ability and knowledge possessed, where one of her given training and education for the field duties and functions authority relating to the handling of Corruption.

- Will minimize interventions that go and do everything possible with the records do not conflict with the provisions of legislation, so that the authority can 
responsible by police institution and become a basic grounding in the handling of criminal acts of corruption, especially in the town of Tasikmalaya Police Institution;

- Empower Infrastructures exist and can be used as appropriate, to the lack of facilities can be used as efficiently as possible, before the submission / procurement of new facilities there;

- Provide guidance / courses / training related to IT (Information Technology), especially in connection with the handling of Corruption;

- Plan, budget and realization of the budget in accordance with the designation, so it will not happen any delays or obstacles in the handling of the case of the Corruption caused by a lack of budget.

- Legislation stating accordance with the authority and the basic tasks and functions of the investigators in the handling of Corruption;

- Providing understanding and education / socialization of the Police Institution adag Society, NGOs and government institutions as well as state / local enterprises which as by covering the retrospective case series of corruption to the Police;

\subsection{Suggestion}

- In order for the government to revise laws that have nothing to add authority to the police in terms of conducting investigations and asset racing against perpetrators of Corruption Act, makes the MoU between the law offical so between law official can be equally accomplished and no egoism among law official enforcement, cone legal devices not overlapping but complementary, and formed the Integrated Institute (Institute for One roof, made up of police, prosecutors, courts and BPK) that specifically deal with Corruption.

- Recruitment Human Resources to act as an Corruption investigator, totally appropriate and feasible, and has the ability to professionals in the field of Criminal Investigation and proportionate in the actions of investigation, the requirement for infrastructure in action investigations, hold exercises briefly about tactics and techniques inquiries and investigations conducted by trainers were professional, and complete the Criminal Unit with a complete library with the duty of all members to read it, the removal of the nature of the arrogance and interests personal of the Investigator, is omitted also the intervention from policy makers and from other institutions against acts of investigation, their lobby through political figures, scholars and religious leaders as well as NGOs, to help provide feedback to lawmakers that the government and legislature, particularly those governing the investigation, in order to avoid discrimination and cone overlapping authority, the need for each investigator is required to attend educational strata of the field of Legal Sciences with budgetary support from the Government as law enforcement Agencies another to master / understand and implement the law accurately and waiver of ego-sectoral nature of the law enforcement apparatus (police, prosecutors, and courts).the need for each investigator is required to attend educational strata of the field of Legal Sciences with budgetary support from the Government such as the Agencies Law Enforcement another to master / understand 
and implement the law accurately and waiver properties sectoral ego of law official enforcement (police, prosecutors, and courts), the need for each investigator is required to attend educational strata of the field of Legal Sciences with budgetary support from the Government such as the Agencies Law Enforcement another to master / understand and implement the law accurately and waiver properties sectoral ego of apparat law enforcement (police, prosecutors, and courts).

\section{Bibliography}

[1] Act No. 3 of 1971 concerning the Eradication of Corruption.

[2] Ali Ahmad. 2008 Menguak Tabir Hukum Bogor Ghalia Indinesia.

[3] Amidhan.2006 Catatan Akhir Tahun 2006 Tentang Pelindungan dan Pemenuhan Hak Ekonomi Sosial dan Budaya Jakarta Komnas Ham.

[4] Asikin Zainal \& Amirudin 2004 Pengantar Penelitian Hukum Jakarta Radja Grafindo Persada.

[5] Atmasasmita Romli 1995 Kapita Selekta Hukum Pidana dan Kriminologi Bandung Mandar Maju.

[6] Constitution of the Republic of Indonesia in 1945.

[7] Military Authorities Regulation No. PRT / PM / 06/1957 On Combating Corruption.

[8] Muladi dan Barda Nawawi Arief Bunga Rampai Hukum Pidana Bandung Alumni 1992

[9] Romli Atmasasmita Prospek Penanggulangan Korupsi di Indonesia Memasuki Abad XXI : Suatu Reorientasi atas Kebijakan Hukum Pidana di Indonesia 1999 Bandung

[10] Romli Atmasasmita Sekitar Masalah Korupsi Aspek Nasional da Aspek Internasional Bandung Mandar Maju 2004

[11] Sahuri Lasmadi "Tumpang tindih kewenangan penyidikan pada tindak pidana korupsi dalam perspektif system peradilan pidana" Makalah Fakultas Hukum Jambi 